\title{
Diversity of Cellulolytic Microbes and the Biodegradation of Municipal Solid Waste by a Potential Strain
}

\author{
S. P. Gautam, ${ }^{1}$ P. S. Bundela, ${ }^{2}$ A. K. Pandey, ${ }^{3}$ Jamaluddin, $^{4}$ M. K. Awasthi, ${ }^{2}$ and S. Sarsaiya ${ }^{2,5}$ \\ ${ }^{1}$ Central Pollution Control Board, New Delhi, India \\ ${ }^{2}$ Regional office, M. P. Pollution Control Board, Vijay Nagar, Jabalpur, India \\ ${ }^{3}$ Mycological Research Laboratory, Department of Biological Sciences, Rani Durgavati University, Jabalpur, India \\ ${ }^{4}$ Yeast and Mycorrhiza Biotechnology Laboratory, Department of Biological Sciences, Rani Durgavati University, \\ Jabalpur, India \\ ${ }^{5}$ International Institute of Waste Management (IIWM), Bhopal, India
}

Correspondence should be addressed to S. Sarsaiya, surendra_sarsaiya@yahoo.co.in

Received 26 July 2011; Revised 10 October 2011; Accepted 31 October 2011

Academic Editor: Thomas L. Kieft

Copyright ( 92012 S. P. Gautam et al. This is an open access article distributed under the Creative Commons Attribution License, which permits unrestricted use, distribution, and reproduction in any medium, provided the original work is properly cited.

\begin{abstract}
Municipal solid waste contains high amounts of cellulose, which is an ideal organic waste for the growth of most of microorganism as well as composting by potential microbes. In the present study, Congo red test was performed for screening of microorganism, and, after selecting a potential strains, it was further used for biodegradation of organic municipal solid waste. Forty nine out of the 250 different microbes tested ( 165 belong to fungi and 85 to bacteria) produced cellulase enzyme and among these Trichoderma viride was found to be a potential strain in the secondary screening. During the biodegradation of organic waste, after 60 days, the average weight losses were $20.10 \%$ in the plates and $33.35 \%$ in the piles. There was an increase in $\mathrm{pH}$ until $20 \mathrm{days}$. $\mathrm{pH}$ however, stabilized after 30 days in the piles. Temperature also stabilized as the composting process progressed in the piles. The high temperature continued until 30 days of decomposition, after which the temperature dropped to $40^{\circ} \mathrm{C}$ and below during the maturation. Good quality compost was obtained in 60 days.
\end{abstract}

\section{Introduction}

In the present technoeconomic era, the energy and environmental crises developed due to huge amount of cellulosic materials are disposed as "waste." Municipal solid waste is composed of $40-50 \%$ cellulose, $9-12 \%$ hemicelluloses, and $10-15 \%$ lignin on a dry weight basis $[1,2]$. Annually, Asia alone generates 4.4 billion tons of solid wastes, and municipal solid waste comprises 790 million tons of which about 48 million tons are generated in India. By the year 2047, municipal solid waste generation in India is expected to reach 300 million tons and land requirement for disposal of this waste would be $169.6 \mathrm{~km}^{2}$. Unscientific disposal causes an adverse impact on all components of the environment and human health. Microorganism performs their metabolic processes rapidly and with remarkable specificity under ambient conditions, catalyzed by their diverse enzyme-mediated reactions. An enzyme alternative to harsh chemical technologies has led to intensive exploration of natural microbial biodiversity to discover enzymes. There is a wide spectrum of microorganisms which can produce the variety of enzymes like cellulase under appropriate conditions.

Cellulases are a consortium of free enzymes comprised of endoglucanases ( $\beta$-1,4-D-glucan-4-glucanohydrolase, EC 3.2.1.4, carboxymethyl cellulase, EC), exoglucanases $(\beta-1,4$ D-glucan-4-glucohydrolase, EC 3.2.1.91, cellobiohydrolase, $\mathrm{CBH})$, and cellobiases ( $\beta$-D-glucoside glucohydrolase, EC 3.2.1.21, $\beta$-1,4-D-glucosidase) are found in many of the 57 glycosyl hydrolase families [3]. Several studies were carried out to produce cellulolytic enzymes in organic waste degradation process by several microorganism including fungi such as Trichoderma sp., Penicillium sp., and Aspergillus spp. respectively [4-6]. Many fungi capable of degrading cellulose synthesize large quantities of extracellular cellulases that are more efficient in depolymerising the cellulose substrate. Most commonly studied cellulolytic organisms 

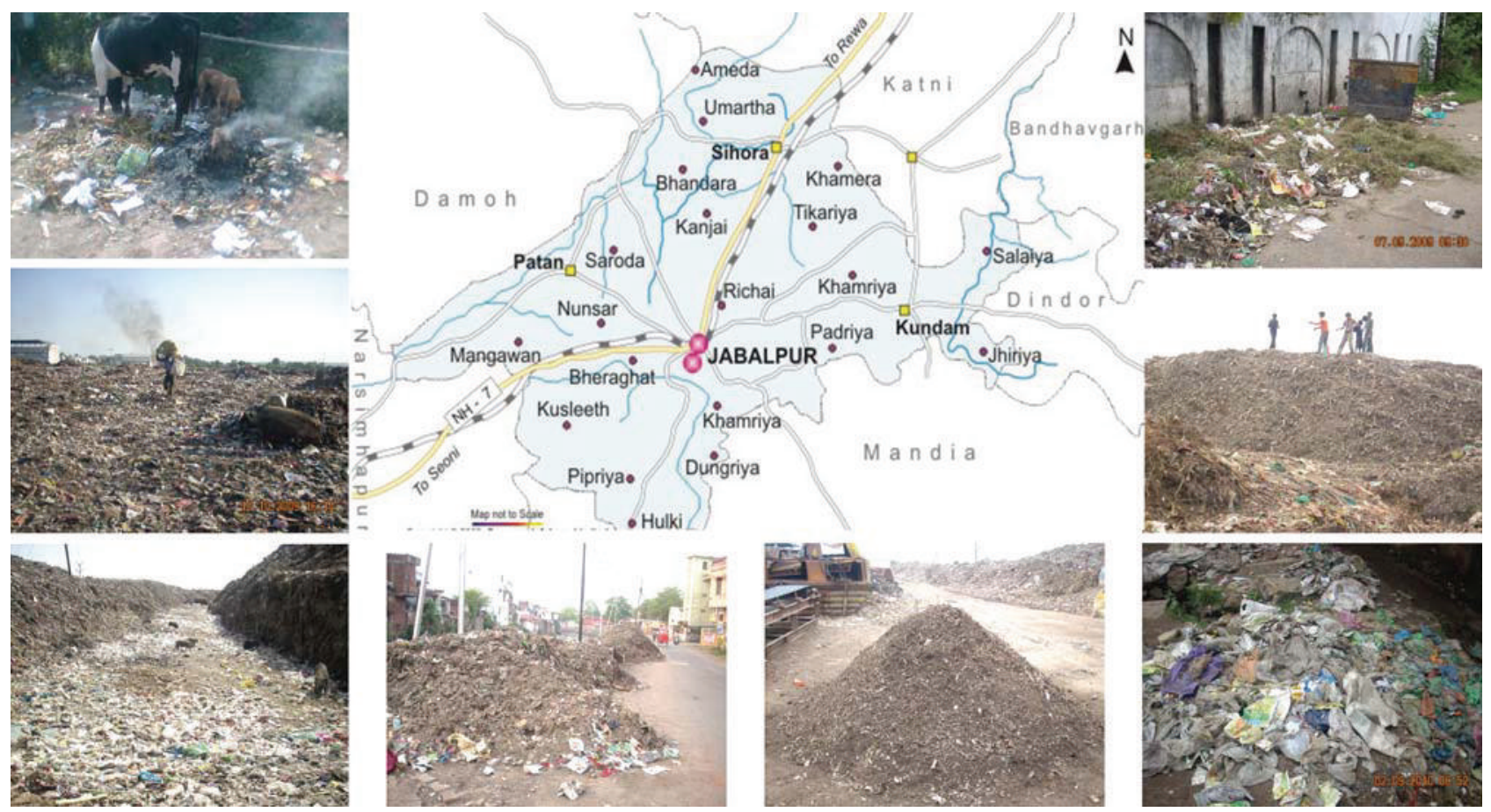

Figure 1: Collection of samples from different waste dump sites of Jabalpur.

include fungal species: Trichoderma, Humicola, Penicillium, and Aspergillus [7]. Among Trichoderma spp., T. harzianum $[8-11]$ and T. koningii $[12,13]$ have been studied. Already an impressive collection of more than 14,000 fungi which were active against cellulose and other insoluble fibres were collected [14]. Many cellulases produced by bacteria appear to be bound to the cell wall and are unable to hydrolyze native lignocellulose preparations to any significant extent. A wide variety of Gram-positive and Gram-negative species are reported to produce cellulose, including Clostridium thermocellum, Streptomyces spp., Ruminococcus spp., Pseudomonas spp., Cellulomonas spp., Bacillus spp., Serratia, Proteus, Staphylococcus spp., and Bacillus subtilis [12, 15]. Various biological studies have been carried out to identify the major microbiological agents responsible for biodegradation. Today, environmental policies and regulation progress lead to the development of biodegradation processes to turn organic wastes into a valuable resource by potential microbes because only few strains are capable of secreting a complex of cellulase enzymes, which could have practical application in the enzymatic hydrolysis of cellulose as well as biodegradation of organic municipal solid waste.

Thus, the present work mainly focused on selecting a potential strain and utilization of cellulosic waste for valueadded products.

\section{Materials and Methods}

2.1. Collection of Samples. Sampling sites were chosen, such that enough cellulose can be accessible naturally, whereby the resident microbial population could predominantly be cellulolytic by nature which could be isolated easily in large numbers. The samples were then brought to the laboratory for microbiological study. Municipal solid waste (MSW), compost, and soil samples collected from different areas of Jabalpur were screened for the isolation of cellulose-degrading microbes. All samples brought to laboratory for isolation were processed within 3-5 h of collection to minimize saprophytic developments (Figure 1).

2.2. Isolation, Identification, and Maintenance of Microbial Strains. Samples were collected from a depth of $2 \mathrm{~cm}$ and were carried to laboratory in sterilized polythene bags. Soil dilution plate method [16] was employed in the present work to isolate different microbes. The $100 \mu \mathrm{L}$ portions $\left(10^{-4} \&\right.$ $10^{-6}$ ) of the suspensions were inoculated onto plates containing potato dextrose agar (PDA) and nutrient agar media (NAM). The plates were incubated at $30 \pm 2^{\circ} \mathrm{C}$ for $4-8$ days. All the isolates obtained from Jabalpur MSW, and composts and soils were identified according to morphological and biochemical basis [17-21]. The identified strains were maintained on PDA and NAM slants at low temperature (4 $\left.\pm 1^{\circ} \mathrm{C}\right)$.

2.3. Primary Screening for Cellulolytic Activity. The isolated microbes were grown on basal salt media supplemented with $1 \%$ carboxymethylcellulose used for both bacteria and fungi [22]. The pure cultures were inoculated in the centre with almost equal amounts and incubated at $30 \pm 2^{\circ} \mathrm{C}$ until substantial growth was recorded. The Petri plates were flooded with Congo red solution (0.1\%), and after $5 \mathrm{~min}$ the Congo red solution was discarded, and the plates were washed with $1 \mathrm{M} \mathrm{NaCl}$ solution allowed to stand for 15 20 minutes. The clear zone was observed around the colony when the enzyme had utilized the cellulose. 
2.4. Secondary Screening for Cellulolytic Activity. Potential microbes presenting large clearing zones in Congo red test were used for enzyme production on basal salt medium containing $1 \%$ cellulose as a sole carbon source [23]. Shake flask technique was used and $150 \mathrm{~mL}$ Erlenmeyer flask filled with $50 \mathrm{~mL}$ of the above medium. After autoclaving, each flask was inoculated with two discs ( $2 \mathrm{~mm}$ diameters) cut from the periphery of 6-day-old culture of fungi actively growing on PDA and a loopful of bacterial culture actively growing on NAM. The flasks were then incubated at $30^{\circ} \mathrm{C}$ in a shaker for 6 days. The flasks were filtered through Whatman number 1 filter paper to separate culture filtrates. The filtrate was analysed for enzyme activities.

2.5. Measurement of Enzyme Activity. Filter paper activity (FPase) for total cellulase activity in the culture filtrate was determined according to the standard method. Aliquots of appropriately diluted cultured filtrate as enzyme source were added to a Whatman number 1 filter paper strip $(1 \times 6 \mathrm{~cm}$; $50 \mathrm{mg}$ ) immersed in one milliliter of $0.05 \mathrm{M}$ sodium citrate buffer of $\mathrm{pH} 4.8$. After incubation at $50 \pm 2^{\circ} \mathrm{C}$ for $1 \mathrm{hrs}$, the reducing sugar released was estimated by dinitrosalicylic acid (DNS) method [24]. One unit of filter paper (FPU) activity was defined as the amount of enzyme-releasing $1 \mu$ mole of reducing sugar from filter paper per $\mathrm{mL}$ per min. Endoglucanase activity (CMCase) was measured using a reaction mixture containing $1 \mathrm{~mL}$ of $1 \%$ carboxymethyl cellulose (CMC) in $0.05 \mathrm{M}$ sodium citrate buffer ( $\mathrm{pH} 4.8$ ) and aliquots of suitably diluted filtrate. The reaction mixture was incubated at $50 \pm 2^{\circ} \mathrm{C}$ for $1 \mathrm{~h}$, and the reducing sugar produced was determined by DNS method [24]. $\beta$-glucosidase activity was assayed by the method of pointing [25]. One unit (IU) of enzyme activity was defined as the amount of enzyme releasing $1 \mu$ mole of reducing sugar per min.

\subsection{Biodegradation of Municipal Solid Waste}

2.6.1. Inoculum Preparation. The fungus used in the study was Trichoderma viride. Two discs of fungal mycelium of T. viride were subcultured in PDA for mass cultivation and incubated at $30 \pm 2{ }^{\circ} \mathrm{C}$ for 6 days. After 144 hours of growth, $5 \%(\mathrm{v} / \mathrm{v})$ of spore suspension of $T$. viride culture was mixed with municipal solid waste for bioconversion [26, 27].

2.6.2. Biodegradation of Municipal Solid Waste. Municipal solid wastes were collected from different waste dumping points of Jabalpur in polythene bags. Samples were cut into small pieces, and $5 \mathrm{~g}$ of each was aliquoted into petri plates, which were then wrapped by using polythene bags. The plates containing municipal solid waste were then autoclaved at $121^{\circ} \mathrm{C}$ for $15 \mathrm{~min}$, and $25 \mathrm{~kg}$ of waste in polythene bags was also autoclaved for preparing piles. After sterilization, the inoculum was inoculated in a petri plate and piles in triplicate. Moisture content was maintained at $50-60 \%$ throughout the active biodegradation in the plates as well as piles. The $\mathrm{pH}$ and temperature were also measured periodically in the piles after 10 days intervals. Turning of the organic waste was provided once in every week to ensure aerobic condition both in the piles and plates. Changes in odour and weight loss of the decomposed organic solid waste were observed at 10-day intervals in the piles and at 30 days in the plates up to 60 days. For measurement of weight loss (\%), the following formula was used:

$$
\text { Weight loss }(\%)=W \frac{W_{1}}{W} \times 100 \text {, }
$$

where $W$ is initial weight, and $W_{1}$ is final weight.

\section{Results and Discussion}

A total of 250 isolates were isolated; of these, 165 belonged to 37 fungal species, and 85 to 21 bacterial species. These were Absidia sp., Alternaria alternata, Alternaria sp., Acremonium butyri, Aspergillus clavatus, Aspergillus flavus, Aspergillus fumigatus, Aspergillus nidulans, Aspergillus niger, Aspergillus candidus, Aspergillus luchuensis, Aspergillus terreus, Aspergillus sp., Chaetomium sp., Chrysosporium sp., Cladosporium sp., Colletotrichum sp., Curvularia lunata, Curvularia sp., Drechslera sp., Exserohilum sp., Fusarium oxysporum, Fusarium roseum, Gliocladium sp., Helminthosporium sp., Humicola sp., Mucor sp., Myrothecium sp., Penicillium digitatum, Penicillium sp., Rhizopus sp., Sclerotium rolfsii, Torula sp., Trichoderma viride, Trichoderma sp., Verticillium sp., MRLB \#38, MRLB \#39, MRLB \#40, MRLB \#41, MRLB \#42, MRLB \#43, MRLB \#44, MRLB \#45, MRLB \#46, MRLB \#47, MRLB \#48, MRLB \#49, MRLB \#50, MRLB \#51, MRLB \#52, MRLB \#53, MRLB \#54, MRLB \#55, MRLB \#56, MRLB \#57, and MRLB \#58 (Table 1). The most frequent fungi were Aspergillus niger, Curvularia lunata, A. nidulans, A. fumigatus, Penicillium sp., Fusarium roseum, and Trichoderma viride, and bacteria were MRLB \#39, MRLB \#42, and MRLB \#44. Most of the above isolates have been reported as cellulase producers, but with variable capabilities by several workers [28-33]. Strom [34] reported that a large majority of the total number of bacterial isolates were members of the genus Bacillus. Proom and Knight [35] studied the bacteria required minimal nutritional requirement. Ezekiel et al. [36] isolated 22 different cellulolytic fungi from different sites. Duncan et al. [37] also isolated 72 fungi and screened for cellulase activity by using the carboxymethyl cellulose (CMC) Congo red plate technique.

3.1. Primary Screening for Cellulolytic Activity. The results of primary screening showed that degradation of cellulose by tested isolates differs from organism to organism. Out of two hundred fifty isolates tested, cellulolytic activity was detected in only 49 different isolates after 4 days of incubations, indicating them to be cellulose degraders. The diameter of the yellow halo varied from organism to organism. The data present in Table 1 revealed that Alternaria alternata, Alternaria sp., Acremonium butyri, Aspergillus clavatus, Aspergillus flavus, Aspergillus candidus, Aspergillus luchuensis, Aspergillus fumigatus, Aspergillus nidulans, Aspergillus niger, Aspergillus terreus, Aspergillus sp., Chaetomium sp., Chrysosporium sp., Cladosporium sp., Curvularia lunata, Curvularia sp., Drechslera sp., Fusarium oxysporum, Fusarium roseum, 


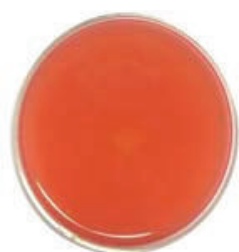

Control

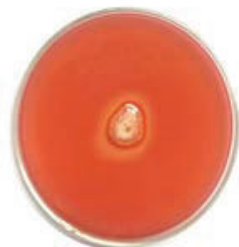

Aspergillus fumigatus

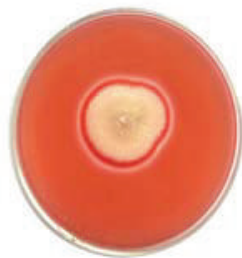

Aspergillus candidus

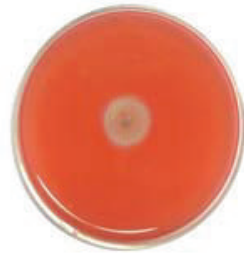

Chaetomium sp.

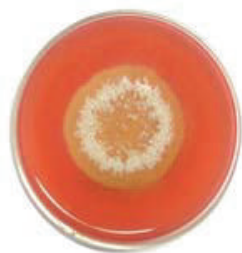

Fusarium oxysporum

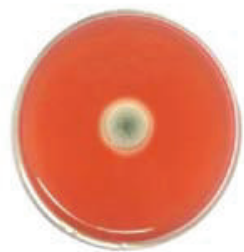

Penicillium sp.

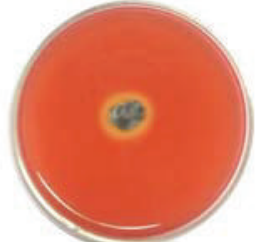

Alternaria alternata

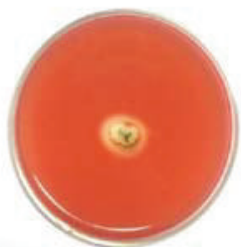

Aspergillus nidulans

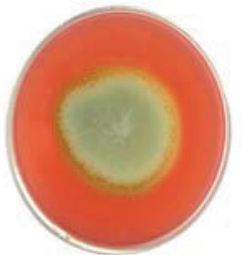

Aspergillus luchuensis

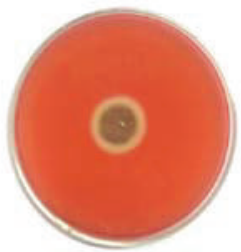

Curvularia lunata

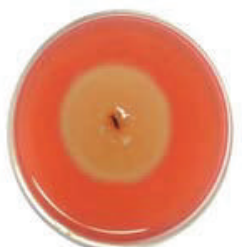

Fusarium roseum

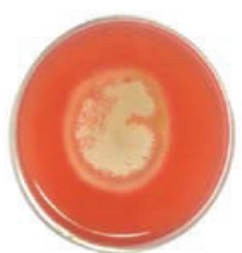

Trichoderma sp.

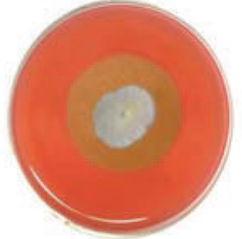

Acremonium butyri

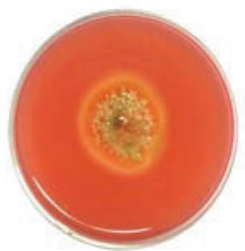

Aspergillus flavus

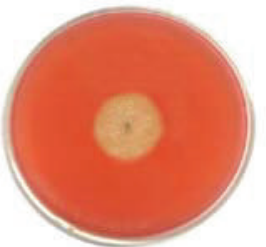

Aspergillus niger

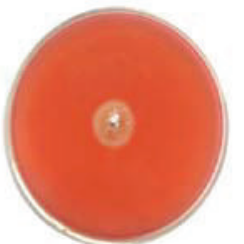

Cladosporium sp.

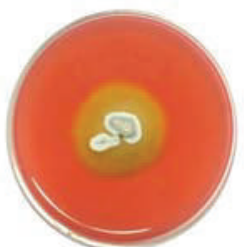

Penicillium digitatum

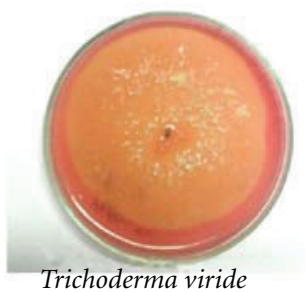

Figure 2: Primary screening of fungi isolated from different sources.

Gliocladium sp., Humicola sp., Mucor sp., Myrothecium sp., Paecilomyces sp., Penicillium digitatum, Penicillium sp., Rhizopus sp., Sclerotium rolfsii, Trichoderma viride, Trichoderma sp., Verticillium sp., MRLB \#38, MRLB \#39, MRLB \#40, MRLB \#42, MRLB \#43, MRLB \#44, MRLB \#45, MRLB \#46, MRLB \#47, MRLB \#49, MRLB \#50, MRLB \#51, MRLB \#53, MRLB \#54, MRLB \#55, MRLB \#56, and MRLB \#57 were active cellulase producers (Figures 2 and 3). On the other hand, Absidia sp., Colletotrichum sp., Exserohilum sp., Helminthosporium sp., Torula sp., MRLB \#41, MRLB \#48, MRLB \#52, and MRLB \#58 were noncellulose producers. The above species were isolated with different numbers and frequencies from various sources in many places of the world by several workers [38-44]. Of the 250 isolates, 49 different 


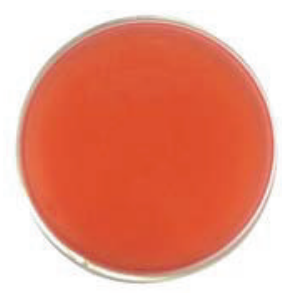

Control

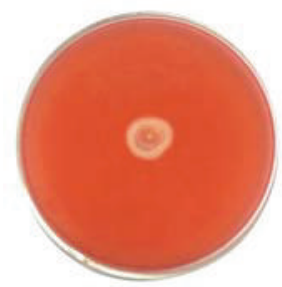

MRLB \#40

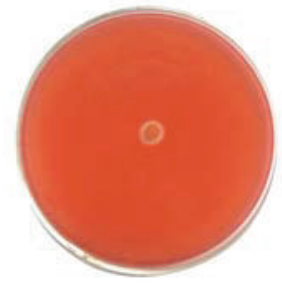

MRLB \#44

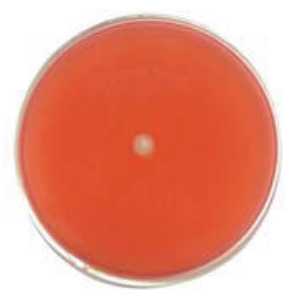

MRLB \#47

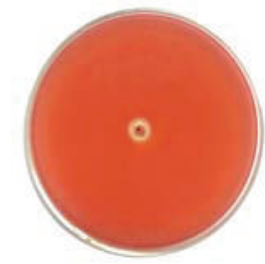

MRLB \#53

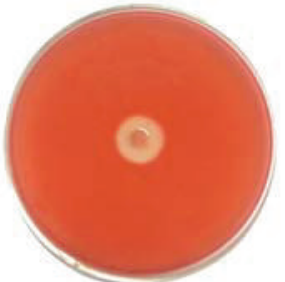

MRLB \#38

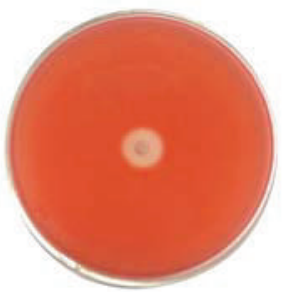

MRLB \#42

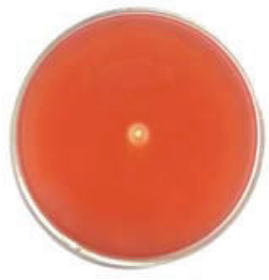

MRLB \#45

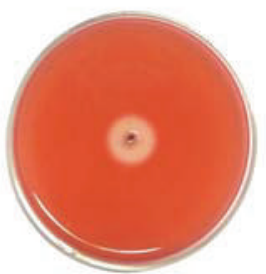

MRLB \#49

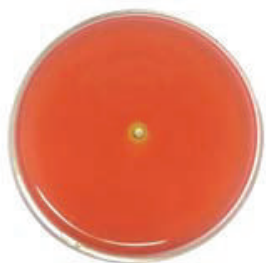

MRLB \#56

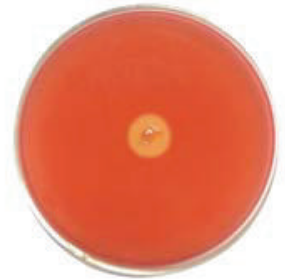

MRLB \#39

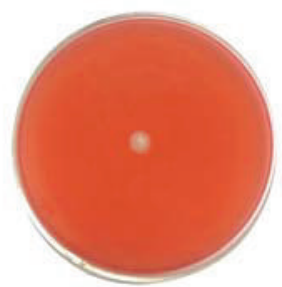

MRLB \#43

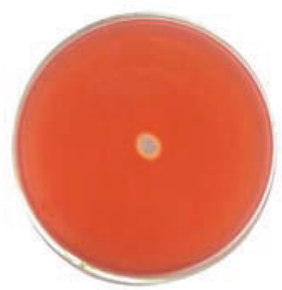

MRLB \#46

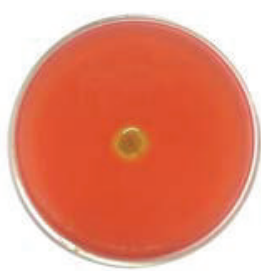

MRLB \#50

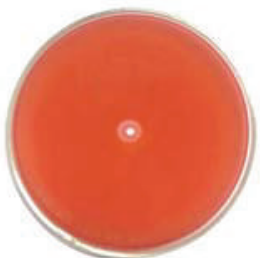

MRLB \#57

FIgURE 3: Primary screening of bacteria isolated from different sources.

isolates were tested for the production of cellulolytic enzyme (secondary screening).

3.2. Secondary Screening for Cellulolytic Activity. It is evident from the results that maximum cellulases activity was observed after the 6th day of incubation at $30^{\circ} \mathrm{C}$ in Trichoderma viride, Penicillium digitatum, Aspergillus niger, Chaetomium sp., and MRLB \#38 and MRLB \#40 followed by Aspergillus fumigatus, Aspergillus nidulans, Alternaria alternata, Aspergillus sp., Fusarium oxysporum, Humicola sp., MRLB \#39, and MRLB \#42. Out of the 49 isolates, exo- $\beta$-glucanase $\left(\mathrm{C}_{1}\right)$ activity in fourteen isolates (Aspergillus flavus $(0.07 \mathrm{IU} / \mathrm{mL}$ ), Aspergillus terreus (0.09 IU/mL), Aspergillus sp. (0.10 IU/ $\mathrm{mL})$, Curvularia lunata $(0.11 \mathrm{IU} / \mathrm{mL})$, Drechslera sp. (0.15 IU/mL), Mucor sp. (0.23 IU/mL), Rhizopus sp. (0.13 IU/ $\mathrm{mL})$, Verticillium sp. $(0.20 \mathrm{IU} / \mathrm{mL})$, MRLB \#42 $(0.08 \mathrm{IU} / \mathrm{mL})$, MRLB \#44 (0.16 IU/mL), MRLB \#51 (0.08 IU/mL), MRLB \#54 (0.14 IU/mL), MRLB \#56 (0.09 IU/mL), and MRLB \#57 $(0.12 \mathrm{IU} / \mathrm{mL}))$ were very low. Maximum exo- $\beta$-glucanase $\left(\mathrm{C}_{1}\right)$ activity was observed by Trichoderma viride (2.22 IU/ $\mathrm{mL})$, Aspergillus niger $(2.05 \mathrm{IU} / \mathrm{mL})$, Fusarium oxysporum 
TABLE 1: Preliminary screening of cellulose-degrading microbes isolated from different sources.

\begin{tabular}{|c|c|c|c|c|c|}
\hline \multirow{2}{*}{ Culture } & \multirow{2}{*}{ Code no. } & \multicolumn{3}{|c|}{ Source } & \multirow{2}{*}{ Zone } \\
\hline & & Soil & MSW & Compost & \\
\hline Absidia sp. & MRLF \#1 & + & - & - & - \\
\hline Alternaria alternata & MRLF \#2 & + & + & + & + \\
\hline Alternaria sp. & MRLF \#3 & + & + & + & + \\
\hline Acremonium butyri & MRLF \#4 & + & + & - & + \\
\hline Aspergillus clavatus & MRLF \#5 & + & + & + & + \\
\hline Aspergillus flavus & MRLF \#6 & + & + & - & + \\
\hline Aspergillus candidus & MRLF \#7 & + & - & - & + \\
\hline Aspergillus luchuensis & MRLF \#8 & + & + & - & + \\
\hline Aspergillus fumigatus & MRLF \#9 & + & + & + & + \\
\hline Aspergillus nidulans & MRLF \#10 & + & + & + & + \\
\hline Aspergillus niger & MRLF \#11 & + & + & + & + \\
\hline Aspergillus sp. & MRLF \#12 & + & - & - & + \\
\hline Aspergillus terreus & MRLF \#13 & - & + & - & + \\
\hline Chaetomium sp. & MRLF \#14 & - & + & - & + \\
\hline Chrysosporium sp. & MRLF \#15 & + & - & - & + \\
\hline Cladosporium sp. & MRLF \#16 & + & + & - & + \\
\hline Colletotrichum sp. & MRLF \#17 & + & + & + & - \\
\hline Curvularia lunata & MRLF \#18 & + & + & + & + \\
\hline Curvularia sp. & MRLF \#19 & + & + & + & + \\
\hline Drechslera sp. & MRLF \#20 & - & + & - & + \\
\hline Exserohilum sp. & MRLF \#21 & - & + & - & - \\
\hline Fusarium oxysporum & MRLF \#22 & + & + & + & + \\
\hline Fusarium roseum & MRLF \#23 & - & + & + & + \\
\hline Gliocladium sp. & MRLF \#24 & + & - & - & + \\
\hline Helminthosporium sp. & MRLF \#25 & - & + & - & - \\
\hline Humicola sp. & MRLF \#26 & + & + & - & + \\
\hline Mucor sp. & MRLF \#27 & + & + & + & + \\
\hline Myrothecium sp. & MRLF \#28 & - & + & - & + \\
\hline Paecilomyces sp. & MRLF \#29 & + & + & - & + \\
\hline Penicillium digitatum & MRLF \#30 & - & - & + & + \\
\hline Penicillium sp. & MRLF \#31 & - & + & - & + \\
\hline Rhizopus sp. & MRLF \#32 & + & + & + & + \\
\hline Sclerotium rolfsii & MRLF \#33 & - & + & + & + \\
\hline Torula sp. & MRLF \#34 & - & + & - & - \\
\hline Trichoderma viride & MRLF \#35 & - & + & + & + \\
\hline Trichoderma sp. & MRLF \#36 & + & + & - & + \\
\hline Verticillium sp. & MRLB \#37 & - & + & + & + \\
\hline Bacteria 1 & MRLB \#38 & - & + & + & + \\
\hline Bacteria 2 & MRLB \#39 & + & + & + & + \\
\hline Bacteria 3 & MRLB \#40 & + & + & - & + \\
\hline Bacteria 4 & MRLB \#41 & + & - & - & - \\
\hline Bacteria 5 & MRLB \#42 & - & + & + & + \\
\hline Bacteria 6 & MRLB \#43 & + & + & + & + \\
\hline Bacteria 7 & MRLB \#44 & + & + & + & + \\
\hline Bacteria 8 & MRLB \#45 & - & - & + & + \\
\hline Bacteria 9 & MRLB \#46 & + & + & - & + \\
\hline Bacteria 10 & MRLB \#47 & + & + & - & + \\
\hline Bacteria 11 & MRLB \#48 & + & - & + & - \\
\hline Bacteria 12 & MRLB \#49 & - & - & + & + \\
\hline Bacteria 13 & MRLB \#50 & + & + & + & + \\
\hline
\end{tabular}


TABLE 1: Continued.

\begin{tabular}{|c|c|c|c|c|c|}
\hline \multirow{2}{*}{ Culture } & \multirow{2}{*}{ Code no. } & \multicolumn{3}{|c|}{ Source } & \multirow{2}{*}{ Zone } \\
\hline & & Soil & MSW & Compost & \\
\hline Bacteria 14 & MRLB \#51 & - & + & + & + \\
\hline Bacteria 15 & MRLB \#52 & + & + & + & - \\
\hline Bacteria 16 & MRLB \#53 & + & - & - & + \\
\hline Bacteria 17 & MRLB \#54 & + & + & - & + \\
\hline Bacteria 18 & MRLB \#55 & + & + & + & + \\
\hline Bacteria 19 & MRLB \#56 & + & + & + & + \\
\hline Bacteria 20 & MRLB \#57 & + & - & + & + \\
\hline Bacteria 21 & MRLB \#58 & + & + & + & - \\
\hline
\end{tabular}

-: Absent; +: present; MSW: municipal solid waste.

(1.14 IU/mL), Fusarium roseum (1.67 IU/mL), Penicillium digitatum (1.38 IU/mL), MRLB \#45 (1.66 IU/mL), MRLB \#38 (1.65 IU/mL) followed by Chaetomium sp. (1.54 IU/mL), Alternaria alternata $(0.30 \mathrm{IU} / \mathrm{mL})$, Aspergillus nidulans (1.19 IU/mL), Humicola sp. (1.28 IU/mL), MRLB \#39 (1.07 IU/mL), MRLB \#47 (1.07 IU/mL), and MRLB \#53 (1.34 IU/mL). Maximum endo- $\beta$-glucanase $\left(\mathrm{C}_{x}\right)$ activity was observed in Trichoderma viride (2.03 IU/mL), Aspergillus niger $(1.76 \mathrm{IU} / \mathrm{mL})$, Aspergillus nidulans $(1.66 \mathrm{IU} / \mathrm{mL})$ and MRLB \#38 (1.81 IU/mL) followed by Chaetomium sp. (1.19 IU/mL), Fusarium oxysporum (1.62 IU/mL), Fusarium roseum (1.21 IU/mL), Humicola sp. (1.43 IU/mL), MRLB \#38 (1.71 IU/mL), MRLB \#45 (1.06 IU/mL), MRLB \#47 $(0.96 \mathrm{IU} / \mathrm{mL})$, and MRLB \#53 $(1.29 \mathrm{IU} / \mathrm{mL})$. On the other hand, Alternaria sp. (0.06 IU/mL), Aspergillus flavus (0.04 IU/ $\mathrm{mL})$, Aspergillus terreus (0.05 IU/mL), Curvularia lunata (0.09 IU/mL), Rhizopus sp. (0.09 IU/mL), MRLB \#42 (0.05 IU/mL), MRLB \#51 (0.11 IU/mL), MRLB \#56 (0.11 IU/ $\mathrm{mL})$, and MRLB \#57 (0.16 IU/mL) were showed very low endo- $\beta$-glucanase activity. $\beta$-glucosidase activity was detected in all the isolates, reaching to its maximum in Trichoderma viride (1.98 IU/mL), Aspergillus niger $(1.96 \mathrm{IU} / \mathrm{mL})$ and Pencillium digitatum (1.53 IU/mL) followed by Aspergillus nidulans (1.54 IU/mL), Chaetomium sp. (1.34 IU/mL), Fusarium oxysporum (1.86 IU/mL), Fusarium roseum $(1.46 \mathrm{IU} / \mathrm{mL})$, Humicola sp. (1.27 IU/mL), Penicillium sp. (1.08 IU/mL), MRLB \#38 (1.59 IU/mL), MRLB \#45 (1.12 IU/mL), and MRLB \#53 (1.36 IU/mL). Reference [45] reported $\beta$-glucosidase production by 39 fungi and found $A$. fumigatus and $A$. nidulans as good $\beta$-glucosidase producers. The maximum $\beta$ glucosidase activity reported by [46] was in Chaetomium cellulotricum. In the present investigation (Table 2), Trichoderma viride was potential strain in the secondary screening and used further for utilization of municipal solid waste for production of value-added product (compost).

3.3. Bioconversion of Municipal Solid Waste. Fungi play an important role in the decomposition of organic waste and can be important contributors to optimal waste bioconversion. For decomposition of organic solid waste by using spore suspension treatment of $T$. viride, no bad smell was emitted after 60 days. It indicates the possible complete degradation of organic waste in plates that contained $5 \mathrm{~g}$ organic waste
(Figure 4). In case of the control, the bad smell continued even after 60 days, and it indicates slow degradation. Data pre-sented in the Figure 6 showed that, after 60 days, the average weight loss in three trials (plates) was $12.51 \%$ and $20.10 \%$. On the other hand, piles that contained $25 \mathrm{~kg}$ of waste in triplicates (Figures 5 and 7) showed that, after 60 days, the average weight loss in three piles was $33.35 \%$ and $11.24 \%$ in control.

During the bioconversion of organic waste, there was a shift in $\mathrm{pH}$ from the initial condition neutral (7.21 and 7.27) toward an alkaline condition in the piles. The occurrence of these conditions may be attributed to the bioconversion of the organic material into various intermediate types of organic acid and higher mineralization of the nitrogen and phosphorous into nitrites/nitrates and orthophosphate, respectively. This increase in $\mathrm{pH}$ during the biodegradation process could be due to the production of ammonium as a result of the ammonification process [47]. Our data show a similar trend (Figure 8) with a fast $\mathrm{pH}$ increase during the first ten days of bioconversion and then stabilization with $\mathrm{pH}$ fluctuations between 7.33 and 7.25 after 30 days. At the beginning of the experiment, the fluctuations can be explained by the industrial process used, involving periodic turnings and consequently the volatilization of $\mathrm{NH}_{4}{ }^{+}$. This acid production results from a lack of oxygen that can occur between two turnings. In such conditions, $\mathrm{pH}$ can reach values of about 6.0 [48]. Our results show that the $\mathrm{pH}$ of composts decreased to a final, mature $\mathrm{pH}$ of approximately 7.40 (control) and 7.26, which meets the compost regulations of $\mathrm{pH}$ 5.0-8.0 for the US, and $\mathrm{pH}$ 5.5-8.0 for the Council of European Communities (CEC) [49].

The initial average temperature of the turned piles was 29 and $31^{\circ} \mathrm{C}$ and rapidly rose to a peak of $58^{\circ} \mathrm{C}$ after 20 days of decomposing. The high temperature continued until 30 days of decomposition, after which the temperature dropped to $36^{\circ} \mathrm{C}$ by the 40 th day of composting. Thereafter, the temperature varied within a narrow range $\left(36-30^{\circ} \mathrm{C}\right.$ ) (Figure 9). The temperature levels in the compost piles tended to increase and reach $40-60^{\circ} \mathrm{C}$ due to the energy released from the biochemical reactions of the microorganisms in the compost piles, while the temperature levels in the compost piles tended to decrease after the thermophilic phase due to a loss of the substrate and a decrease in microbial activity [50]. It 
TABLE 2: Secondary screening of cellulose-producing microorganism.

\begin{tabular}{|c|c|c|c|c|}
\hline \multirow{2}{*}{ Culture } & \multirow{2}{*}{ Code no. } & \multicolumn{3}{|c|}{ Enzyme activity (IU/mL) } \\
\hline & & Exoglucanase & Endoglucanase & $\beta$-glucosidase \\
\hline Alternaria alternata & MRLF \#2 & $0.30 \pm 0.02$ & $0.58 \pm 0.03$ & $0.16 \pm 0.01$ \\
\hline Alternaria sp. & MRLF \#3 & $0.19 \pm 0.01$ & $0.06 \pm 0.007$ & $0.12 \pm 0.01$ \\
\hline Acremonium butyri & MRLF \#4 & $0.32 \pm 0.01$ & $0.45 \pm 0.02$ & $0.29 \pm 0.01$ \\
\hline Aspergillus clavatus & MRLF \#5 & $0.46 \pm 0.02$ & $0.52 \pm 0.03$ & $0.40 \pm 0.03$ \\
\hline Aspergillus flavus & MRLF \#6 & $0.07 \pm 0.003$ & $0.04 \pm 0.005$ & $0.10 \pm 0.008$ \\
\hline Aspergilluscandidus & MRLF \#7 & $0.43 \pm 0.02$ & $0.36 \pm 0.01$ & $0.50 \pm 0.02$ \\
\hline Aspergillus luchuensis & MRLF \#8 & $0.65 \pm 0.02$ & $0.71 \pm 0.04$ & $0.53 \pm 0.04$ \\
\hline Aspergillus fumigatus & MRLF \#9 & $0.72 \pm 0.03$ & $0.58 \pm 0.03$ & $0.85 \pm 0.05$ \\
\hline Aspergillus nidulans & MRLF \#10 & $1.19 \pm 0.05$ & $1.66 \pm 0.06$ & $1.54 \pm 0.06$ \\
\hline Aspergillus niger & MRLF \#11 & $2.05 \pm 0.06$ & $1.76 \pm 0.06$ & $1.96 \pm 0.06$ \\
\hline Aspergillus terreus & MRLF \#12 & $0.09 \pm 0.005$ & $0.05 \pm 0.006$ & $0.08 \pm 0.005$ \\
\hline Aspergillus sp. & MRLF \#13 & $0.10 \pm 0.007$ & $0.14 \pm 0.01$ & $0.13 \pm 0.01$ \\
\hline Chaetomium sp. & MRLF \#14 & $1.54 \pm 0.04$ & $1.19 \pm 0.05$ & $1.34 \pm 0.05$ \\
\hline Chrysosporium sp. & MRLF \#15 & $0.29 \pm 0.01$ & $0.37 \pm 0.02$ & $0.26 \pm 0.01$ \\
\hline Cladosporium sp. & MRLF \#16 & $0.82 \pm 0.05$ & $0.91 \pm 0.05$ & $0.65 \pm 0.04$ \\
\hline Curvularia lunata & MRLF \#18 & $0.11 \pm 0.01$ & $0.09 \pm 0.005$ & $0.15 \pm 0.01$ \\
\hline Curvularia sp. & MRLF \#19 & $0.32 \pm 0.06$ & $0.39 \pm 0.04$ & $0.27 \pm 0.01$ \\
\hline Drechslera sp. & MRLF \#20 & $0.15 \pm 0.04$ & $0.17 \pm 0.01$ & $0.21 \pm 0.02$ \\
\hline Fusarium oxysporum & MRLF \#22 & $1.14 \pm 0.07$ & $1.62 \pm 0.06$ & $1.86 \pm 0.06$ \\
\hline Fusarium roseum & MRLF \#23 & $1.67 \pm 0.06$ & $1.21 \pm 0.04$ & $1.46 \pm 0.05$ \\
\hline Gliocladium sp. & MRLF \#24 & $0.61 \pm 0.03$ & $0.78 \pm 0.04$ & $0.59 \pm 0.03$ \\
\hline Humicola sp. & MRLF \#26 & $1.28 \pm 0.04$ & $1.43 \pm 0.05$ & $1.27 \pm 0.06$ \\
\hline Mucor sp. & MRLF \#27 & $0.23 \pm 0.01$ & $0.41 \pm 0.02$ & $0.32 \pm 0.02$ \\
\hline Myrothecium sp. & MRLF \#28 & $1.21 \pm 0.05$ & $0.99 \pm 0.03$ & $0.91 \pm 0.04$ \\
\hline Paecilomyces sp. & MRLF \#29 & $0.51 \pm 0.02$ & $0.84 \pm 0.03$ & $0.64 \pm 0.03$ \\
\hline Penicillium digitatum & MRLF \#30 & $1.38 \pm 0.06$ & $1.37 \pm 0.05$ & $1.53 \pm 0.06$ \\
\hline Penicillium sp. & MRLF \#31 & $0.91 \pm 0.03$ & $0.72 \pm 0.03$ & $1.08 \pm 0.04$ \\
\hline Rhizopus sp. & MRLF \#32 & $0.13 \pm 0.009$ & $0.09 \pm 0.006$ & $0.14 \pm 0.007$ \\
\hline Sclerotium rolfsii & MRLF \#33 & $0.67 \pm 0.03$ & $0.71 \pm 0.05$ & $0.68 \pm 0.04$ \\
\hline Trichodermaviride & MRLF \#35 & $2.22 \pm 0.07$ & $2.03 \pm 0.06$ & $1.98 \pm 0.06$ \\
\hline Trichoderma sp. & MRLF \#36 & $0.76 \pm 0.04$ & $0.78 \pm 0.04$ & $0.69 \pm 0.03$ \\
\hline Verticillium sp. & MRLF \#37 & $0.20 \pm 0.02$ & $0.17 \pm 0.01$ & $0.27 \pm 0.01$ \\
\hline Bacteria 1 & MRLB \#38 & $1.65 \pm 0.06$ & $1.71 \pm 0.06$ & $1.59 \pm 0.05$ \\
\hline Bacteria 2 & MRLB \#39 & $1.07 \pm 0.05$ & $0.96 \pm 0.04$ & $0.94 \pm 0.04$ \\
\hline Bacteria 3 & MRLB \#40 & $0.73 \pm 0.04$ & $0.67 \pm 0.03$ & $0.52 \pm 0.03$ \\
\hline Bacteria 5 & MRLB \#42 & $0.08 \pm 0.006$ & $0.05 \pm 0.003$ & $0.11 \pm 0.006$ \\
\hline Bacteria 6 & MRLB \#43 & $0.32 \pm 0.02$ & $0.24 \pm 0.01$ & $0.29 \pm 0.01$ \\
\hline Bacteria 7 & MRLB \#44 & $0.16 \pm 0.01$ & $0.19 \pm 0.009$ & $0.14 \pm 0.008$ \\
\hline Bacteria 8 & MRLB \#45 & $1.66 \pm 0.04$ & $1.06 \pm 0.04$ & $1.12 \pm 0.06$ \\
\hline Bacteria 9 & MRLB \#46 & $0.76 \pm 0.04$ & $0.61 \pm 0.02$ & $0.68 \pm 0.04$ \\
\hline Bacteria 10 & MRLB \#47 & $1.07 \pm 0.06$ & $0.96 \pm 0.03$ & $0.89 \pm 0.05$ \\
\hline Bacteria 12 & MRLB \#49 & $0.21 \pm 0.02$ & $0.30 \pm 0.02$ & $0.27 \pm 0.01$ \\
\hline Bacteria 13 & MRLB \#50 & $0.64 \pm 0.03$ & $0.72 \pm 0.04$ & $0.35 \pm 0.02$ \\
\hline Bacteria 14 & MRLB \#51 & $0.08 \pm 0.007$ & $0.11 \pm 0.009$ & $0.13 \pm 0.008$ \\
\hline Bacteria 16 & MRLB \#53 & $1.34 \pm 0.06$ & $1.29 \pm 0.05$ & $1.36 \pm 0.04$ \\
\hline Bacteria 17 & MRLB \#54 & $0.14 \pm 0.01$ & $0.20 \pm 0.01$ & $0.18 \pm 0.009$ \\
\hline Bacteria 18 & MRLB \#55 & $0.28 \pm 0.02$ & $0.16 \pm 0.01$ & $0.19 \pm 0.007$ \\
\hline Bacteria 19 & MRLB \#56 & $0.09 \pm 0.007$ & $0.11 \pm 0.01$ & $0.13 \pm 0.01$ \\
\hline Bacteria 20 & MRLB \#57 & $0.12 \pm 0.009$ & $0.16 \pm 0.01$ & $0.14 \pm 0.004$ \\
\hline
\end{tabular}

Values are means \pm SEm of the three observations. 

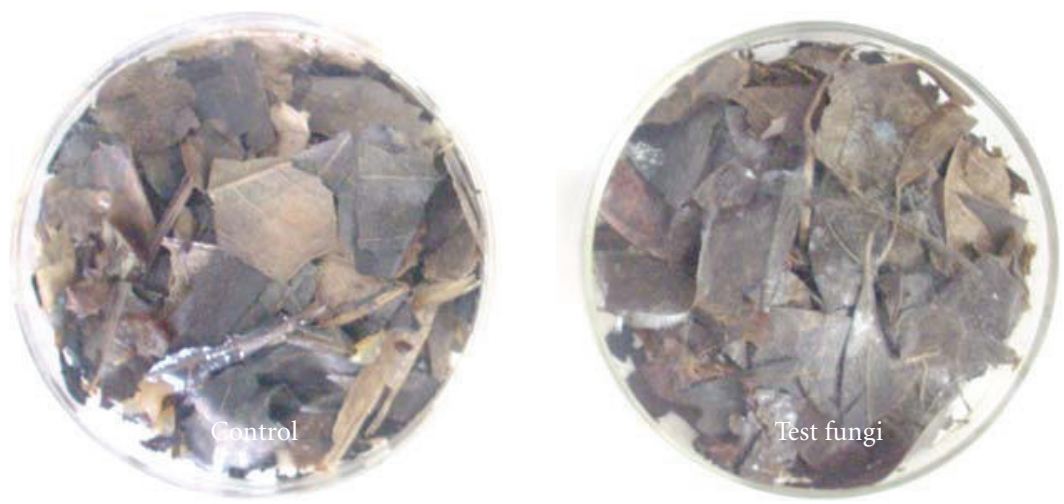

Plate 1: Municipal solid waste (day 0)

(a)
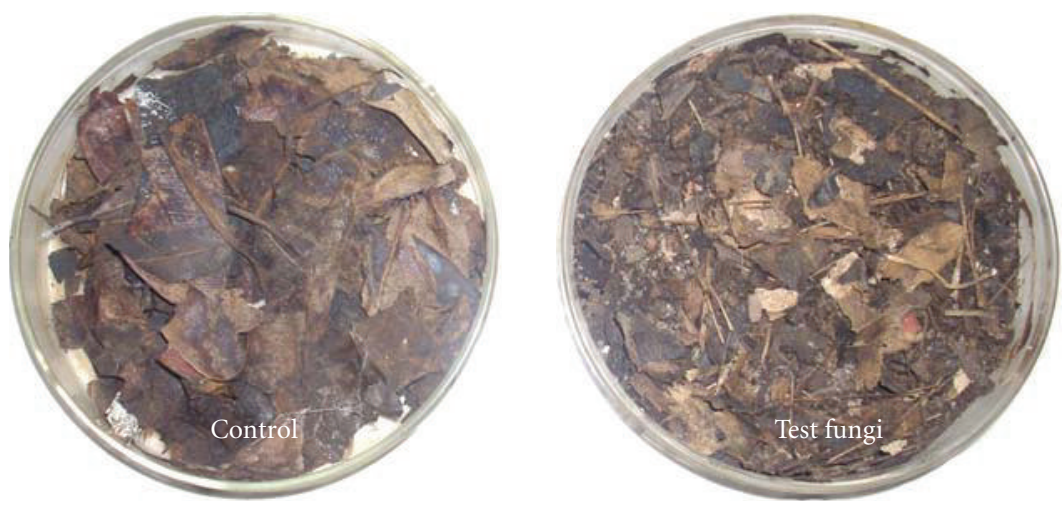

Plate 2: Municipal solid waste (day 30)

(b)
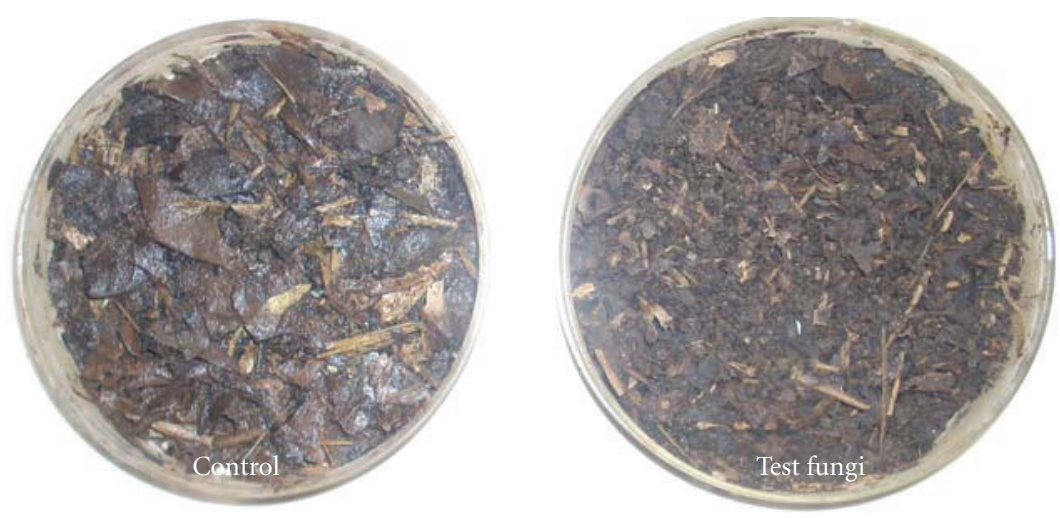

Plate 3: Municipal solid waste (day 60)

(c)

FIGURE 4: Bioconversion of municipal solid waste by using spore suspension of T. viride in petri plates.

was previously reported that the compost material can be considered mature when an ambient temperature of $28^{\circ} \mathrm{C}$ is reached [51]. Therefore, this parameter is considered as a good indicator for the end of the biooxidative phase in which the compost achieves some degree of maturity [52-54]. After 60 days, the mature compost was black in color, granular, and fibrous with a pleasant earthy smell. The appearance of black color indicated its maturity. In the case of the control (without culture), the biodegradation was very slow, and weight loss was also low. In order to assess the compost maturity, both the compost samples were placed separately in a sealed polythene bags for a week. After a week, the sealed bags were broken, and the odor was checked, which was found to have earthy smell in the compost produced by $T$. viride, 


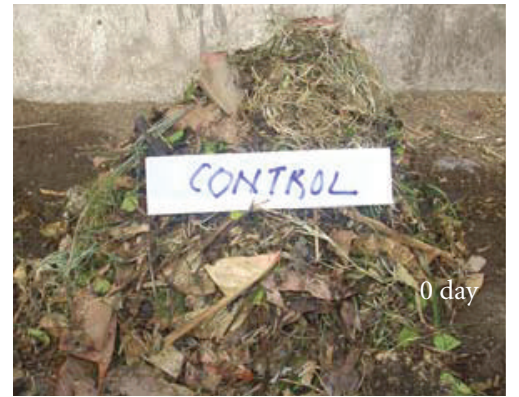

(a)

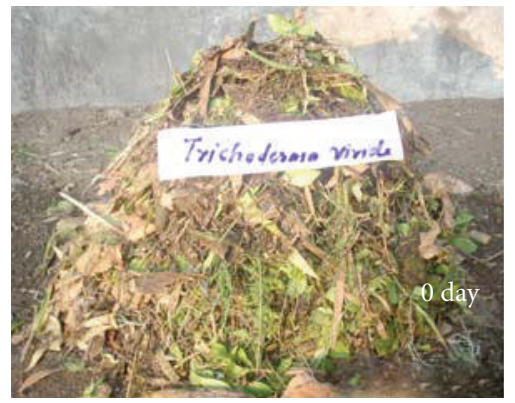

(d)

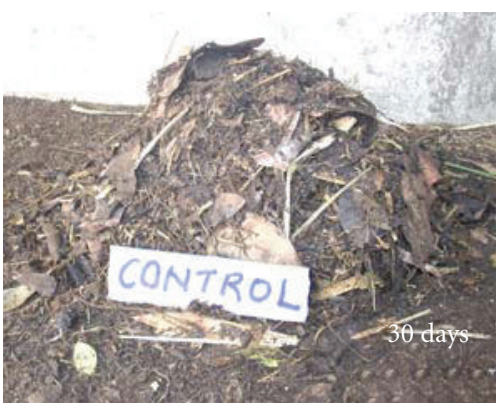

(b)

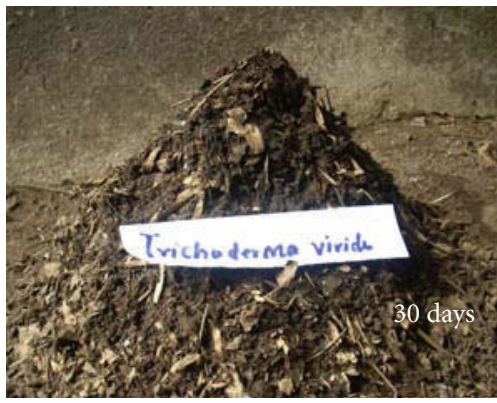

(e)

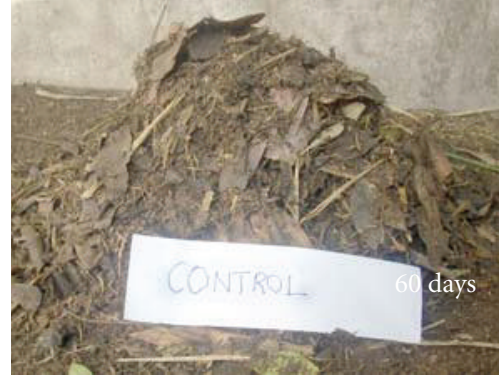

(c)

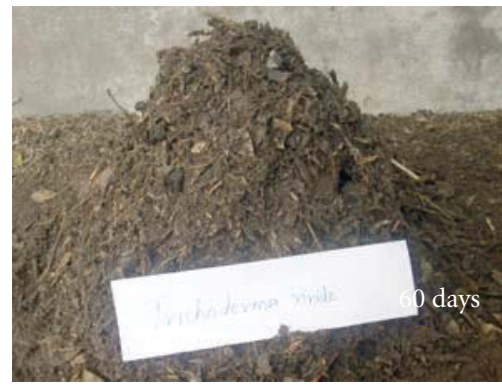

(f)

FIGURE 5: Bioconversion of municipal solid waste by T. viride using spore suspension in small piles.

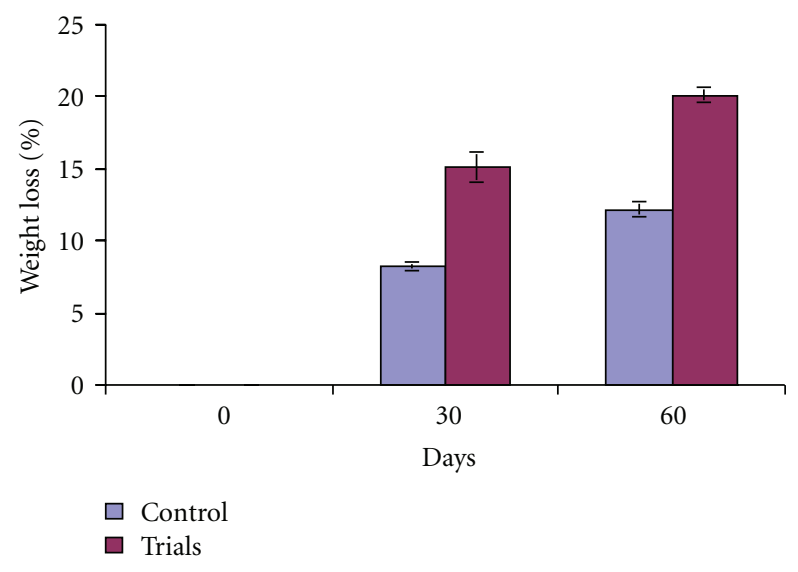

Figure 6: Percent weight loses of municipal solid waste by spore suspension of $T$. viride in plates $(5 \mathrm{~g})$.

indicating the quality of stable and mature compost and compost produced by without treated T. viride, produced bed smell after one week. These findings are in accordance with the previous study where it was reported that mature compost produces an earthy smell after being sealed in the polythene bag for a week [55].

\section{Conclusions}

From the above findings, it can be concluded that a large number of microorganism were found in municipal solid

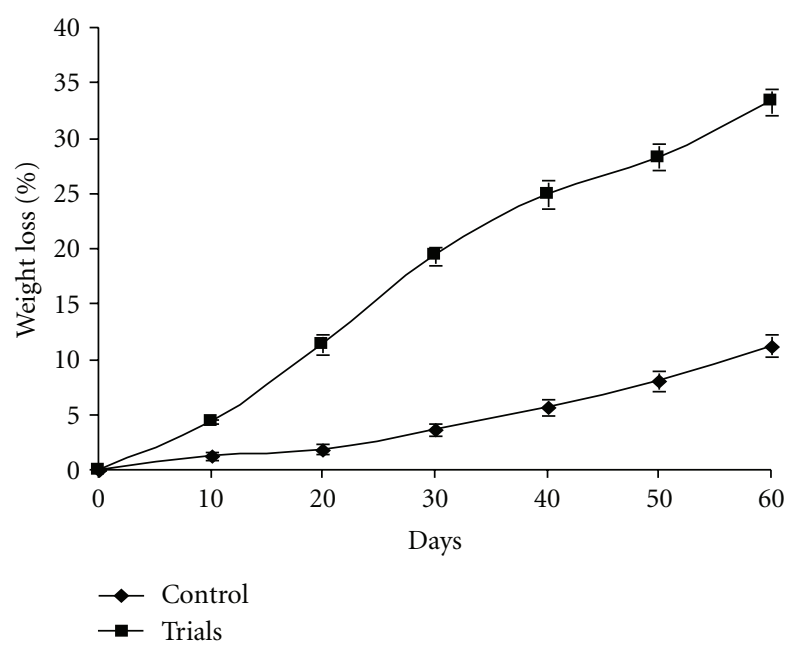

FIGURE 7: Percent weight loses of municipal solid waste by spore suspension of T. viride in open piles $(25 \mathrm{Kg})$.

waste, compost, and soil. Municipal solid waste is suitable for composting because of the presence of high percentages of organic matter. The T. viride had promising effects in the decomposition of organic municipal solid waste, resulting in a greater bioconversion of the original material than the control. Therefore, $\mathrm{pH}$ and temperature were considered as a good indicator for the end of the bioconversion of municipal solid waste in which the compost achieves some degree of maturity. 


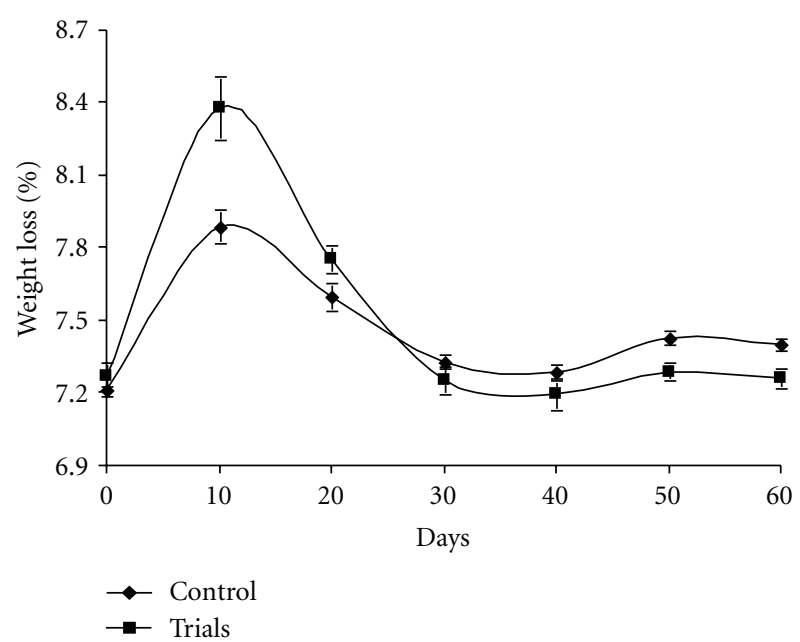

FIGURE 8: Variation of $\mathrm{pH}$ during the bioconversion of MSW.

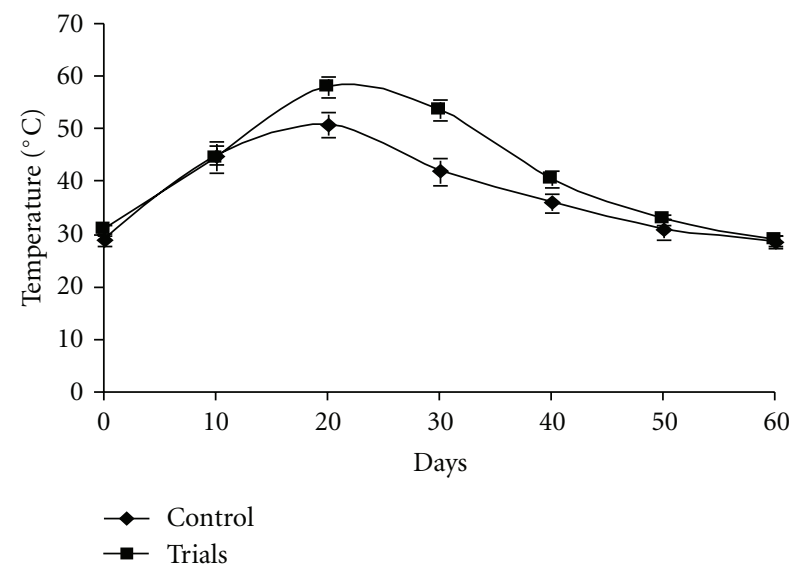

FIGURE 9: Variation of temperature during the bioconversion of MSW.

\section{Acknowledgments}

The authors are thankful to M. P. Pollution Control Board Bhopal and Head and Department of Biological Sciences, R.D. University, Jabalpur, for laboratory facilities. Ministry of Environment and Forest New Delhi is also thankfully acknowledged for financial support.

\section{References}

[1] D. S. Rani and K. Nand, "Production of thermostable cellulase-free xylanase by Clostridium absonum CFR-702," Process Biochemistry, vol. 36, no. 4, pp. 355-362, 2000.

[2] S. P. Gautam, P. S. Bundela, A. K. Pandey, M. K. Awasthi, and S. Sarsaiya, "Composting of municipal solid waste of Jabalpur City," Global Journal of Environmental Research, vol. 4, no. 1, pp. 43-46, 2010.

[3] K. S. Siddiqui, A. A. N. Saqio, M. H. Rashid, and M. I. Rajoka, "Carboxyl group modification significantly altered the kinetic properties of purified carboxymethyl cellulase from Aspergillus niger," Enzyme Microbial Technology, vol. 27, pp. 467-474, 2000.
[4] M. Mendals, "Microbial sources of cellulases," Biotechnology Bioengineering, no. 5, pp. 81-105, 1975.

[5] J. A. Brown, S. A. Collin, and T. M. Wood, "Development of a medium for high cellulase, xylanase and $\beta$-glucosidase production by a mutant strain (NTG III/6) of the cellulolytic fungus Penicillium pinophilum," Enzyme and Microbial Technology, vol. 9, no. 6, pp. 355-360, 1987.

[6] S. P. Gautam, P. S. Bundela, A. K. Pandey, M. K. Awasthi, and S. Sarsaiya, "Effect of different carbon sources on production of Cellulases by Aspergillus niger," Journal of Applied Science Environmental Sanitation, vol. 5, no. 3, pp. 277-281, 2010.

[7] S. P. Gautam, P. S. Bundela, A. K. Pandey, M. K. Awasthi, and S. Sarsaiya, "Prevalence of fungi in Municipal solid waste of Jabalpur city (M.P.)," Journal of Basic \& Applied Mycology, vol. 8, no. 1-2, pp. 80-81, 2009.

[8] F. C. Deschamps, C. Giuliano, M. Asther, M. C. Huet, and S. Roussos, "Cellulase production by Trichoderma harzianum in static and mixed solid state fermentation reactors under nonaseptic conditions," Biotechnology and Bioengineering, vol. 27, no. 9, pp. 1385-1388, 1985.

[9] B. J. Macris, M. Paspaliari, and D. Kekos, "Production and cross-synergistic action of cellulolytic enzymes from certain fungal mutants grown on cotton and straw," Biotechnology Letters, vol. 7, no. 5, pp. 369-372, 1985.

[10] J. N. Saddler, M. K. H. Chan, M. Mes, Hartree, and C. Brevil, "Cellulase production and hydrolysis of pretreated lignocelluloses substrate in biomass conversion technology," in Principles and Practice, M. Moo Young, Ed., Pciqumon Press, 1987.

[11] D. B. Wilson, "Microbial diversity of cellulose hydrolysis," Current Opinion in Microbiology, vol. 14, pp. 259-263, 2011.

[12] T. M. Wood and K. M. Bhat, "Methods for measuring cellulase activities," in Methods in Enzymology, W. A. Wood and S. T. Kellogg, Eds., vol. 160, p. 87, Academic Press, New York, NY, USA, 1988.

[13] T. M. Wood and S. I. McCrae, "Purification and some properties of a $(1 \rightarrow 4)$ - $\beta$-d-glucan glucohydrolase associated with the cellulase from the fungus Penicillium funiculosum," Carbohydrate Research, vol. 110, no. 2, pp. 291-303, 1982.

[14] M. Mandels and D. Sternberg, "Recent advances in cellulases technology," Journal of Fermentation Technology, vol. 54, no. 4, pp. 267-286, 1976.

[15] S. P. Gautam, P. S. Bundela, A. K. Pandey, Jamaluddin, M. K. Awasthi, and S. Sarsaiya, "Cellulase production by Pseudomonas sp. isolated from municipal solid waste compost," International Journal of Academic Research, vol. 2, no. 6, pp. 330-333, 2010.

[16] S. A. Waksman, Principles of Soil Microbiology, Williams \& Wilkins, Baltimore, Md, USA, 1927.

[17] K. B. Raper and C. Thom, A Manual of the Penicillia, Williams \& Wilkins, Baltimore, Md, USA, 1949.

[18] J. L. Barnett and B. B. Hunter, Illustrated Genera of Imperfect Fungi, Burgess Publishing Company, Minneapolis, Minn, USA, 1972.

[19] M. B. Ellis, Demataceous Hyphomycetes, Commonwealth Mycological Institute, Kew, UK, 1971.

[20] M. B. Ellis, Demataceous Hyphomycetes, Commonwealth Mycological Institute, Kew, UK, 1976.

[21] M. Goodfellow and S. T. Williams, Bergey's Manual of Systematic Bacteriology, vol. 4, 1989.

[22] L. Hankin and L. Anagnostaksis, "The use of solid media for detection of enzyme production by fungi," Mycologia, vol. 47, pp. 597-607, 1975.

[23] A. A. Sherief, A. B. El-Tanash, and N. Atia, "Cellulase production by Aspergillus fumigatus grown on mixed substrate of 
rice straw and wheat bran," Research Journal of Microbiology, vol. 5, no. 3, pp. 199-211, 2010.

[24] G. L. Miller, "Use of dinitrosalicylic acid reagent for determination of reducing sugar," Analytical Chemistry, vol. 31, no. 3, pp. 426-428, 1959.

[25] S. B. Pointing, "Qualitative methods for the determination of lignocellulolytic enzyme production by tropical fungi," Fungal Diversity, vol. 2, pp. 17-33, 1999.

[26] R. Elango and J. Divakaran, "Microbial consortium for effective composting of coffee pulp waste by enzymatic activities," Global Journal of Environmental Research, vol. 3, no. 2, pp. 9295, 2009.

[27] A. Rahman, M. F. Begum, M. Rahman, and M. A. Bari, "Isolation and identification of Trichoderma species from different habitats and their use for bioconversion of solid waste," Turk Journal of Biology, vol. 34, pp. 1-12, 2010.

[28] B. Abrha and B. A. Gashe, "Cellulase production and activity in a species of Cladosporium," World Journal of Microbiology \& Biotechnology, vol. 8, no. 2, pp. 164-166, 1992.

[29] S. I. I. Abdel-Hafez, A. H. M. El-Said, and Y. A. M. H. Gherabawy, "Mycoflora of leaf surface, stem, bagasse and juice of adult sugarcane (Saccharum officinarum L.) plant and cellulolytic ability in Egypt," A Bulletin of the Faculty of Science, vol. 24, pp. 113-130, 1995.

[30] A. I. I. Abdel-Hafez, S. I. I. Abdel-Hafez, S. M. Mohawed, and A. H. M. El-Said, "Composition, occurrence and cellulolytic activities of fungi in habiting soils along Idfu-Marsa Alam road at Eastern desert, Egypt," A Bulletin of the Faculty of Science, vol. 20, pp. 21-48, 1991.

[31] A. M. Moharram, S. I. I. Abdel-Hafez, and M. A. Abdel-Star, "Cellulolytic activity of fungi isolated from different substrates from the New Valley Governorate, Egypt," Pure Science Engineering, vol. 1, pp. 101-114, 1995.

[32] A. H. M. El-Said, "Phyllosphere and phylloplane fungi of banana cultivated in Upper Egypt and their cellulolytic ability," Mycobiology, vol. 29, pp. 210-217, 2001.

[33] A. Berlin, N. Gilkes, D. Kilburn et al., "Evaluation of novel fungal cellulase preparations for ability to hydrolyze softwood substrates-Evidence for the role of accessory enzymes," Enzyme and Microbial Technology, vol. 37, no. 2, pp. 175-184, 2005.

[34] P. F. Strom, "Identification of thermophilic bacteria in solidwaste composting," Applied and Environmental Microbiology, vol. 50, no. 4, pp. 906-913, 1985.

[35] H. Proom and B. C. J. G. Knight, "The minimal nutritional requirements of some species in the genus Bacillus," Journal of General Microbiology, vol. 13, no. 3, pp. 474-480, 1955.

[36] C. N. Ezekiel, A. C. Odebode, R. O. Omenka, and F. A. Adesioye, "Growth response and comparative cellulase induction in soil fungi grown on different cellulose media," Acta SATECH, vol. 3, no. 2, pp. 52-59, 2010.

[37] S. M. Duncan, R. L. Farrell, J. M. Thwaites et al., "Endoglucanase-producing fungi isolated from Cape Evans historic expedition hut on Ross Island, Antartica," Environonmental Microbialogy, vol. 8, no. 7, pp. 1212-1219, 2006.

[38] S. P. Gautam, P. S. Bundela, A. K. Pandey, M. K. Awasthi, and S. Sarsaiya, "Screening of cellulolytic fungi for management of municipal solid waste," Journal of Applied Science for Environmental Sanitation, vol. 5, no. 4, pp. 367-371, 2010.

[39] A. I. I. Abdel-Hafez, S. I. I. Abdel-Hafez, S. M. Mohawed, and T. A. M. Ahmed, "Seasonal fluctuations of soil and air borne fungi at Qena, Upper Egypt," A Bulletin of the Faculty of Science, vol. 19, pp. 47-63, 1990.
[40] S. P. Gautam, P. S. Bundela, A. K. Pandey, Jamaluddin, M. K. Awasthi, and S. Sarsaiya, "Fusarium sp. from municipal solid waste compost: ability to produce extracellular cellulases enzyme," International Journal of Biotechnology and Bioengineering Research, vol. 2, no. 2, pp. 239-245, 2010.

[41] A. H. Moubasher and M. B. Mazen, "Assay of cellulolytic activity of cellulose-decomposing fungi isolated from Egyptian soils," Journal of Basic Microbiology, vol. 31, pp. 59-66, 1991.

[42] S. I. I. Abdel-Hafez, "Studies on soil mycoflora of desert soils in Saudi Arabia," Mycopathologia, vol. 80, pp. 3-8, 1994.

[43] R. Karl and M. Y. Iain, "Interactions between soil structure and fungi,” Mycologist, vol. 18, no. 2, pp. 52-59, 2004.

[44] J. S. Lalley and H. A. Viles, "Terricolous lichens in the northern Namib desert of Namibia: distribution and community composition," Lichenologist, vol. 37, no. 1, pp. 77-91, 2005.

[45] A. P. S. Sandhu, G. S. Randhawa, and K. S. Dhugga, "Plant cell wall matrix polysaccharide biosynthesis," Molecular Plant, vol. 2, no. 5, pp. 840-850, 2009.

[46] D. K. Sandhu and M. K. Kalra, "Effect of cultural conditions on production of cellulases in Trichoderma longibrachiatum," Transactions of the British Mycological Society, vol. 84, pp. 251258, 1985.

[47] G. F. Huang, J. W. C. Wong, Q. T. Wu, and B. B. Nagar, "Effect of $\mathrm{C} / \mathrm{N}$ on composting of pig manure with sawdust," Waste Management Research, vol. 24, no. 8, pp. 805-813, 2004.

[48] C. Sundberg, S. Smars, and H. Jonsson, "Low pH as an inhibiting factor in the transition from mesophilic to thermophilic phase in composting," Bioresource Technology, vol. 95, no. 2, pp. 145-150, 2004.

[49] B. Felicita, H. Nina, V. Marija, and G. Zoran, "Aerobic composting of tobacco industry solid waste-simulation of the process," Clean Technology Environmental Policy, vol. 5, pp. 295-301, 2003.

[50] M. Bertoldi, G. Vallini, and A. Pera, "The biology of composting: a review," Waste Management and Research, vol. 1, no. 2, pp. 157-176, 1983.

[51] S. M. Tiquia, N. F. Y. Tam, and I. J. Hodgkiss, "Effects of bacterial inoculum and moisture adjustment on composting of pig manure," Environmental Pollution, vol. 96, no. 2, pp. 161-171, 1997.

[52] S. P. Gautam, P. S. Bundela, A. K. Pandey, M. K. Awasthi, and S. Sarsaiya, "Isolation, identification and cultural optimization of indigenous fungal isolates as a potential bioconversion agent of municipal solid waste," Annals of Environmental Science, vol. 5, 2010.

[53] S. P. Gautam, P. S. Bundela, A. K. Pandey, Jamaluddin, M. K. Awasthi, and S. Sarsaiya, "Optimization of the medium for the production of cellulase by the Trichoderma viride using submerged fermentation," International Journal of Environmental Science, vol. 1, no. 4, pp. 656-665, 2010.

[54] E. I. Jimenez and V. P. Garcia, "Evaluation of city refuse compost maturity: a review," Biological Wastes, vol. 27, no. 2, pp. 115-142, 1989.

[55] S. Jilani, "Municipal solid waste composting and its assessment for reuse in plant production," Pakistan Journal of Botany, vol. 39, no. 1, pp. 271-277, 2007. 

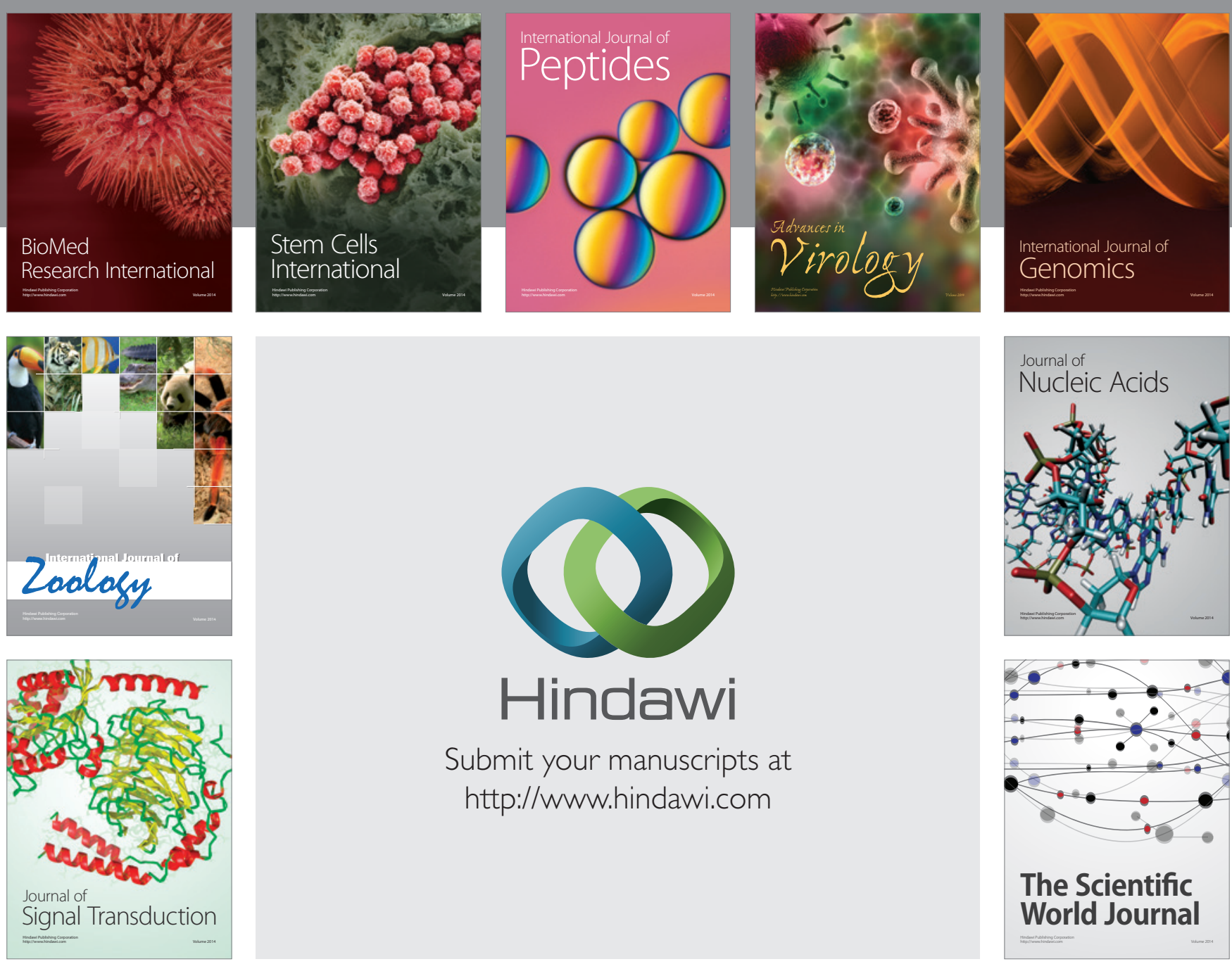

Submit your manuscripts at

http://www.hindawi.com
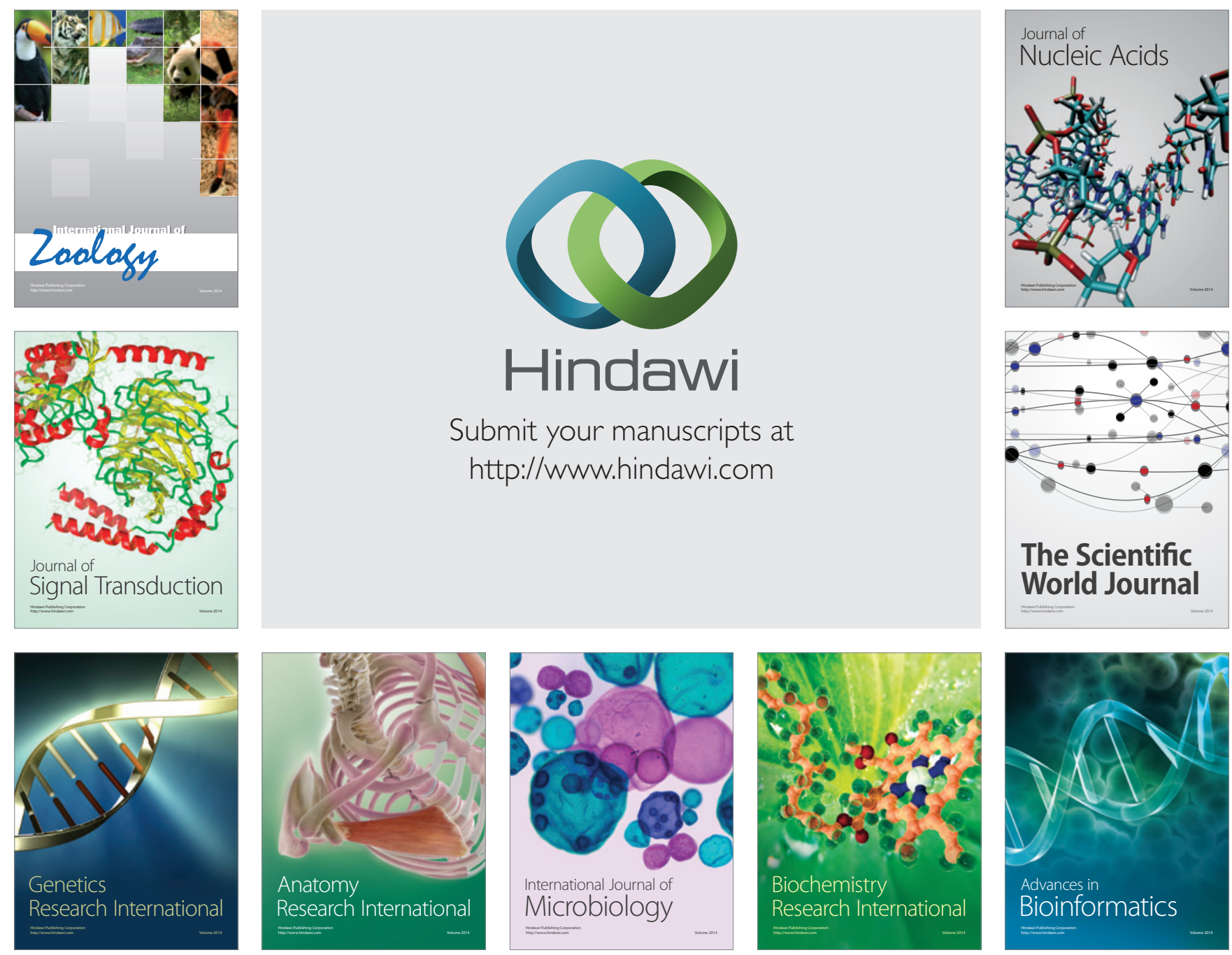

The Scientific World Journal
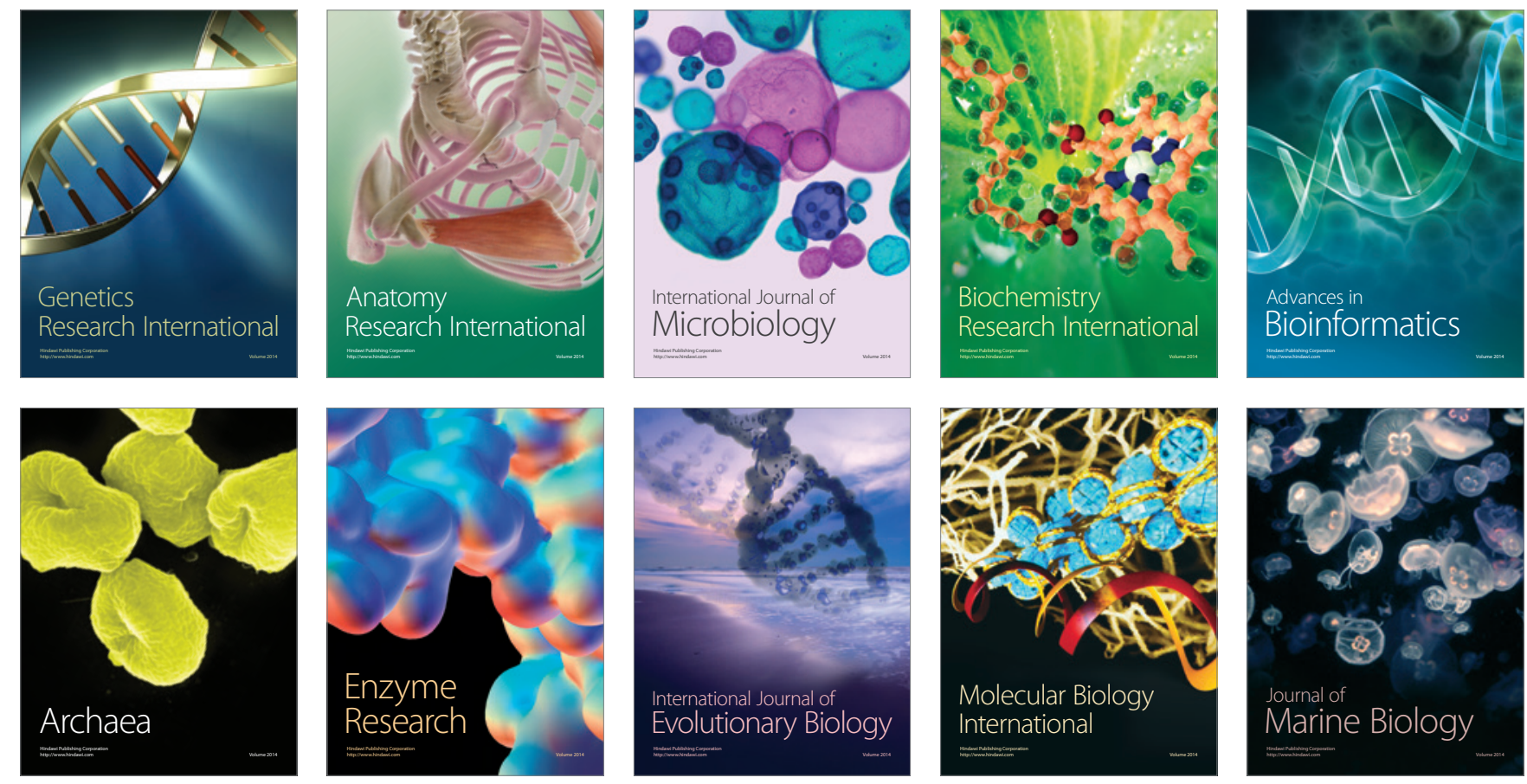